\title{
UNFEASIBLE EXPERIMENTAL MODEL OF NORMOTHERMIC HEPATIC ISCHEMIA AND REPERFUSION IN RATS USING THE PRINGLE MANEUVER
}

\author{
Modelo experimental inviável de isquemia e reperfusão hepática normotérmica em ratos utilizando a manobra de pringle \\ Helbert Minuncio Pereira GOMES, Leonardo Carvalho SERIGIOLLE, Daren Athiê Boy RODRIGUES, \\ Carolina Marques LOPES, Sarah do Valle STUDART, Pedro Luiz Squilacci LEME
}

From the Laboratório de Habilidades Cirúrgicas Avançadas da Universidade Nove de Julho (Laboratory of Advanced Surgical Skills at University Nove de Julho), São Paulo, SP, Brazil.

HEADINGS - Models, animal. Scientific misconduct. Liver/surgery. Portal vein. Reperfusion injury.
ABSTRACT - Background: The negative result of a research does not always indicate failure, and when the data do not permit a proper conclusion, or are contrary to the initial project, should not simply be discarded and archived. Aim: To report failure after performing experimental model of liver ischemia and reperfusion normothermic, continuous or intermittent, in small animals aiming at the study of biochemical and histological parameters after postoperative recovery. Methods: Fifteen Wistar rats were divided into three groups of five animals each; all underwent surgery, the abdomen was sutured after the proposed procedures for each group and the animals were observed for $6 \mathrm{~h}$ or until they died, and then were reoperated. In Group 1, control (sham-operated): dissection of the hepatic hilum was performed; in Group 2: clamping of the hepatic hilum for $30 \mathrm{~m}$; in Group 3: clamping of the hepatic hilum for $15 \mathrm{~m}$, reperfusion for $5 \mathrm{~m}$ and another $15 \mathrm{~m}$ of clamping. Data from Groups 2 and 3 were compared with Student's t test. Results: All animals of Group 1 survived for 6 h. Two animals in Group 2 died before the $6 \mathrm{~h}$ needed to validate the experiment; two did not recover from anesthesia and one survived until the end. In Group 3, four animals died before the $6 \mathrm{~h}$ established and one of them survived the required time. Only one animal in Group 2 and one in Group 3 survived and were able to accomplish the study. There was no statistical significance when the results of Groups 2 and 3 were compared ( $p>0.05$ ). Conclusion: The death of six animals before the necessary period of observation turned the initial proposal of the experiment unfeasible.

\section{Correspondence:}

Helbert Minuncio Pereira Gomes

E-mail: helbert_mpg@hotmail.com

Financial source: none

Conflicts of interest: none

Received for publication: 27/02/2014 Accepted for publication: 13/05/2014

DESCRTORES - Modelos animais. Má conduta científica. Fígado/cirurgia. Veia porta. Traumatismo por reperfusão.
RESUMO - Racional: O resultado negativo de uma pesquisa nem sempre indica falha, e quando os dados obtidos não permitem uma conclusão adequada, ou ainda, são contrários ao projeto inicial, não devem simplesmente ser desprezados e arquivados. Objetivo: Relatar falha ao realizar em animais de pequeno porte modelo experimental de isquemia e reperfusão hepática normotérmica, contínua ou intermitente, visando estudar parâmetros bioquímicos e histológicos após a recuperação pós-operatória. Métodos: Quinze ratos da linhagem Wistar foram divididos em três grupos com cinco animais cada; todos foram operados, a cavidade abdominal foi suturada após os procedimentos propostos para cada grupo e os ratos foram observados por $6 \mathrm{~h}$ ou até morrerem, quando foram reoperados. Foram realizados no Grupo 1, controle (sham-operated): dissecção do hilo hepático; no Grupo 2: pinçamento do hilo hepático por $30 \mathrm{~m}$; no Grupo 3: pinçamento do hilo hepático por $15 \mathrm{~m}$, reperfusão do fígado por $5 \mathrm{~m}$ e mais $15 \mathrm{~m}$ de pinçamento. Os dados dos grupos 2 e 3 foram comparados com o teste t de Student. Resultados: Todos os animais do Grupo 1 sobreviveram 6 h. Dois do Grupo 2 morreram antes das $6 \mathrm{~h}$ necessárias para a validação do experimento, dois não se recuperaram da primeira anestesia e um sobreviveu até o final. No Grupo 3, quatro animais morreram antes das $6 \mathrm{~h}$ previstas e um sobreviveu o tempo necessário. Apenas um animal do Grupo 2 e um do Grupo 3 sobreviveu ou se encontrava em condições para a complementação do estudo. Não houve significância estatística quando os resultados dos Grupos 2 e 3 foram comparados $(p>0,05)$. Conclusão: A morte de seis animais antes do período de observação necessário após a primeira operação inviabilizou a proposta inicial do experimento.

A Ithough scientific publications of unexpected results obtained with experiments in the English language are presented more frequently, there are few of these reports in Brazilian publications. The negative result of a research does not always indicate failure, and when the data do not allow a proper conclusion, or else, are contrary to the initial project, they should not simply be discarded and filed. The acquisition of knowledge with possible errors, preventing other researchers repeat the same method of study, justifies the publication of unfavorable results, a practice that should be estimulated ${ }^{2,20,25}$.

In 1908 James Hogarth Pringle ${ }^{21}$ described the maneuver that now bears his name, compressing the structures of the hepatic hilum (portal vein, hepatic artery and bile duct), to decrease the bleeding and allow the treatment of severe traumatic injuries in eight patients. This valuable tactic is used in liver trauma, in performing elective liver surgeries and experimental surgery with satisfactory results. It is usually performed in humans with periods of $15 \mathrm{~min}$. of portal triad clamping, interspersed with $5 \mathrm{~min}$. of reperfusion in patients with normal hepatic function and $10 \mathrm{~min}$. of vascular occlusion 
interspersed with the same $5 \mathrm{~min}$. reperfusion when the liver function is compromised ${ }^{28}$.

Experimental models can be developed with this maneuver, which produces transient ischemia of liver tissues, as well as splanchnic venous congestion and intestinal ischemia, with significant metabolic acidosis, being useful for the study of shock ${ }^{9,10}$. As the veins of the digestive system mainly drain for the portal system, changes can also be found in the intestine, spleen $^{10}$ and pancreas ${ }^{29}$. Studies in rats are usually performed only until the end of the period proposed for ischemia and reperfusion, not being expected the survival of animals after the completion of the Pringle maneuver with data collection after a few hours of reperfusion. When survival is required, usually larger animals are used, such as rabbits ${ }^{14,21 .}$

Studies motivated by the development of liver transplants started using ischemia and reperfusion denomination from the 1980s. Lesions in this situation occur with greater intensity when an ischemic organ receives oxygen supply $3,8,18,22,23,29$; this phenomenon corresponds to the mobilization of hydrogen ions, free radicals, enzymes and electrolytes like potassium, reaching the systemic circulation when ischemic tissues are reperfused rapidly, with significant repercussions ${ }^{\mathbf{8 , 1 2}}$. After reperfusion, sistemic phenomena dependent on leukocytes and free radicals occur, which include endothelial dysfunction, injury to organs other than the initially compromised, systemic inflammatory response syndrome (SIRS) and multiple organ failure. The remote lesion is due to oxidative stress mediators, arachidonic acid derivatives, metals and nitric oxide, representing an extensive experimental field of study, $3,5,18$

Thus, the report on the failure to develop an experimental model should be considered important, since these data can help other researchers, avoiding wasting time with models already tested, as well as the precepts of rational use of experimental animals ${ }^{15}$, motivating the disclosure of this study, which could not be completed.

\section{METHODS}

This experiment was conducted at the Laboratory of Advanced Surgical Skills at Universidade Nove de Julho, São Paulo, SP, Brazil after being approved by the Ethics Committee on Animal Use of the University (protocol 0041/2012). The care with the preparation of the animals, anesthesia, postoperative analgesia and general care at the vivarium were strictly supervised in the institution and followed specific protocols ${ }^{24}$. As the mortality of animals was significant, in respect to ethical principles of animal experimentation, the experimental model was discontinued without the study of biochemical parameters such as the dosage of bicarbonate, the evaluation of $\mathrm{pH}$, blood gases and histological study of the liver were performed.

Before the surgical procedures, the rats remained in individual cages with access to water and standardized ration ad libitum, maintained at a temperature of $25^{\circ} \mathrm{C}$, light and dark cycles of $12 \mathrm{~h}$. The animals were weighed, anesthetized with intraperitoneal injection of ketamine $(50 \mathrm{mg} / \mathrm{kg})$ and xylazine (10 mg/kg), a midline laparotomy was made and, after the proposed procedures for each of the three groups were made, the operation was finalized with suture of the anterior abdominal wall in layers with 4-0 nylon suture.

Fifteen Wistar rats (Rattus norvegicus albinus) were used, weighing on average 210-370 g, divided randomly into three groups of five animals each. The 15 rats were operated and observed for $6 \mathrm{~h}$ or until they died, when they were reoperated. It was performed in Group 1, control (shamoperated): dissection of the hepatic hilum (Figure 1). In Group 2, clamping of the hepatic hilum for $30 \mathrm{~min}$. obtained by traction of the suture thread used in the dissection. In Group 3, clamping of the hepatic hilum for $15 \mathrm{~min}$., reperfusion of the liver for $5 \mathrm{~min}$. and $15 \mathrm{~min}$. more clamped. The data from groups 2 and 3 were compared with Student's t-test.

\section{RESULTS}

Congestion of the splanchnic vessels was observed after the first $15 \mathrm{~min}$. of vascular occlusion (Group 3), including stomach and abdominal esophagus, confirming that the clamping was done adequately, above the outfall of the left gastric vein in portal vein (Figure 2-a). The tributaries of the superior mesenteric vein also showed significant congestion, confirming that the effect of the Pringle maneuver occurs not only in the liver (Figure 2-b)

When, in Group 3, was realized hepatic reperfusion for $5 \mathrm{~min}$., it was noted that some mesenteric vessels remained turgid (Figure 3-a) and small intestine macroscopically showed early signs of edema and circulatory changes (Figure 3-b).

One animal in Group 2 (continuous clamping) and Group 3 (intermittent clamping) survived the $6 \mathrm{~h}$ required for the completion of the study. These two animals were anesthetized again and reoperated, but showed signs of significant impairment of liver and bowel (Figure 4).

Six out of 16 animals (40\%) who died before the necessary $6 \mathrm{~h}$ and the two that did not recover from the first anesthesia could not be used for data collection and the experiment was stopped. When the death of these animals were found it was proceeded to the opening of the stiches of the abdominal cavity and all of them showed extensive lesions of the small intestine, petechiae in the intestinal wall, and bloody exudate in the peritoneal cavity (Figure 5 ).

The study predicted the survival of rats for $6 \mathrm{~h}$, when biochemical and histological parameters would be evaluated, but the overall mortality of $40 \%$ (six out of 15 animals failed to survive the planned $6 \mathrm{~h}$ ), occurring death of two animals (13.3 $\%$ ) within $6 \mathrm{~h}$ in the group in which continuous compression of the portal triad for 30 min. was applied (group 2) as well as the death of four animals (26.6\%) in which hepatic reperfusion for $5 \mathrm{~min}$. between two periods of $15 \mathrm{~min}$. compression of the hepatic hilum was performed (group 3), made the study infeasible. The two animals in Group 2 that did not recovered from the first anesthesia could not be used either (Table 1).

\section{DISCUSSION}

Although Pringle's ${ }^{21}$ studies have been published for over 100 years (1908), they must now be read not only with historical focus, but for its current concepts reported there. The author mentions that minor lacerations of the liver can be treated conservatively, but in serious injury the surgery must be immediate and the hepatic hilum should be rapidly compressed; the study makes direct reference to the word shock, that although it was first described in 1743 and whose characterization of physiological instability associated with this condition is of $1815^{9}$, it is classically considered that these concepts were widespread only later, due to the First World War (1914-18). His article reports the greater severity of blunt trauma than direct injury from penetrating trauma, quotes mortality statistics and epidemiology of these injuries, reports the performed necropsies, discusses thoracic and abdominal trauma, multiple traumas, cites intra-abdominal pressure, tatics for liver suture and presents material for the synthesis of hepatic tissue specially developed for the author. The effects of compression of the hepatic pedicle on intestinal circulation were also mentioned in this pioneering article, which described the treatment of eight patients in Glasgow, as well as Pringle's experimental study in rabbits, 


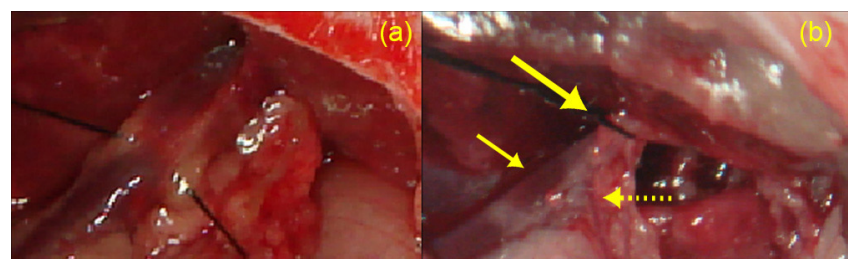

FIGURE 1-a) Dissection and repair with suture thread of the hepatic hilum; b) image obtained with the aid of a surgical microscope, the larger arrow shows the portal vein, the smallest indicates the superior mesenteric vein and the dashed arrow shows the splenic vein

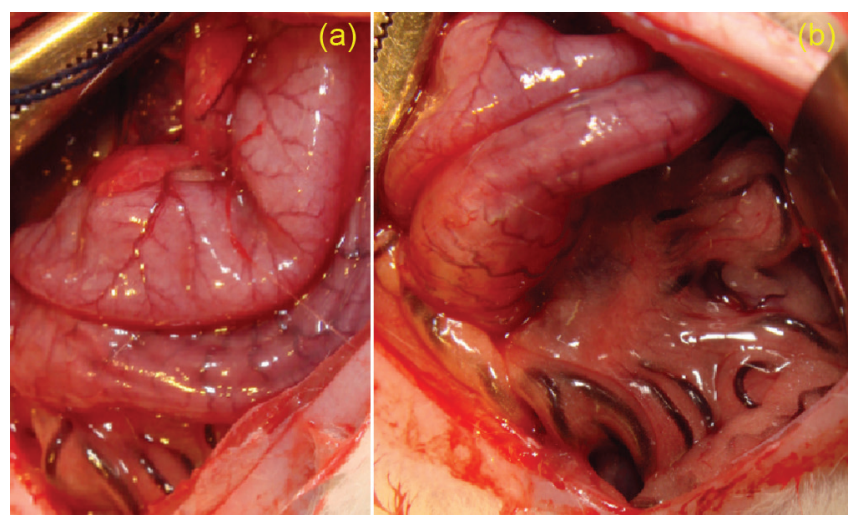

FIGURE 2 - Aspect of the viscera after 15 min. clamping of the hepatic hilum (Group 3): a) intense and early venous congestion of the splanchnic territory; b) and in the tributaries of the superior mesenteric vein, showing impact of Pringle maneuver not only in hepatic perfusion

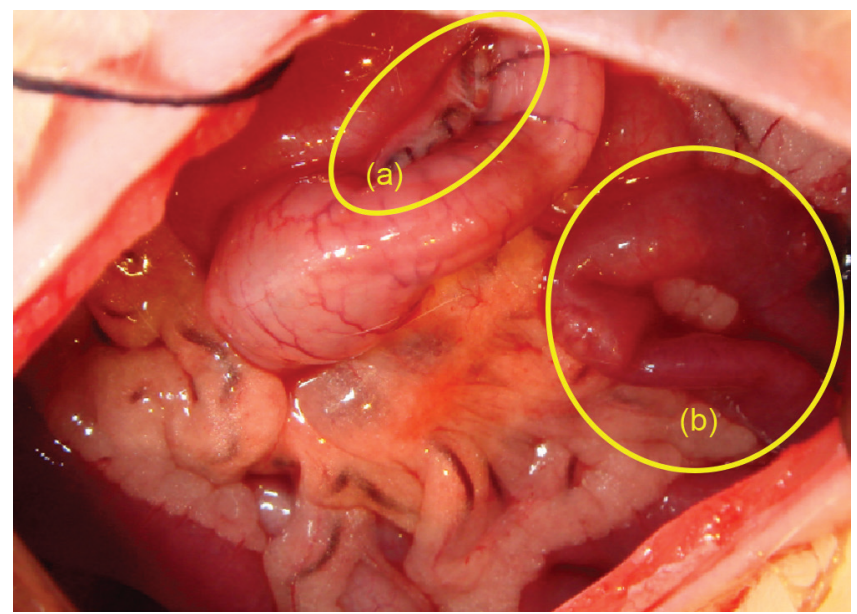

FIGURA 3 - Appearance of the abdominal cavity after 5 min. reperfusion, $15 \mathrm{~min}$. after the initial clamping of the hepatic hilum (Group 3); venous congestion persisted (a) even after this period of reperfusion; edema and macroscopic signs suggestive of early circulatory disorders are noted (b)

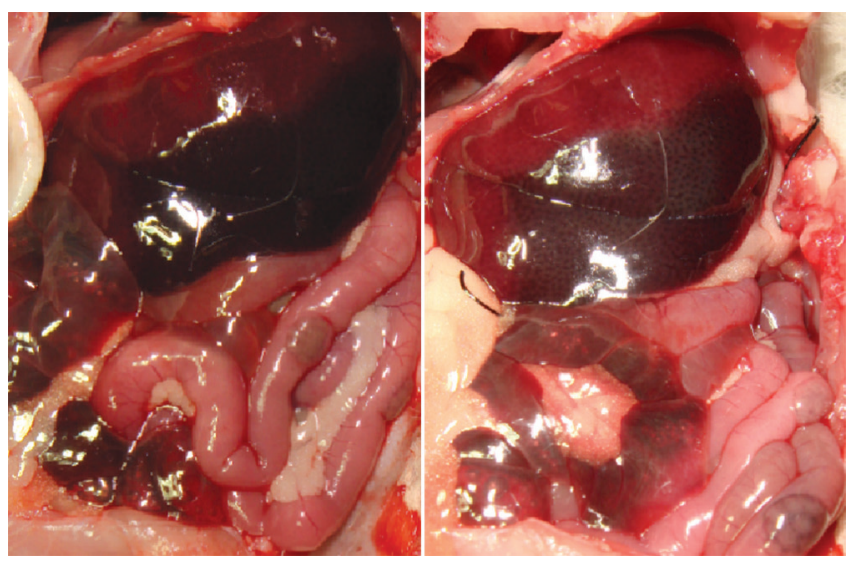

FIGURA 4 - Appearance of liver and bowel of the animals that survived until the end of the experiment $(6 \mathrm{~h})$; both continuous and intermittent ischemia was accompanied by significant late repercussions

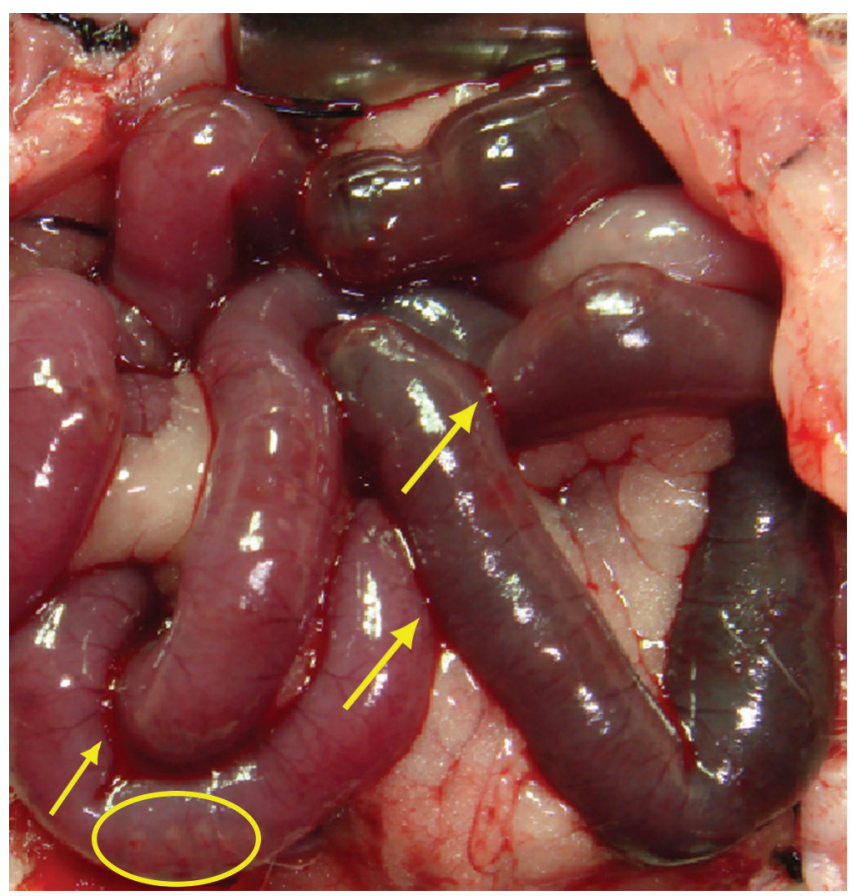

FIGURE 5 - Appearance of bowel with edema and signs of vascular distress of the animal that did not survive until the end of the proposed study; petechiae are noted in the intestinal loop wall (highlighted) and bloody exudate in the peritoneal cavity (arrows)

TABLE 1 - Period of ischemia and mortality of animals in Groups 2 and 3: only one animal from each group survived 6 $\mathrm{h}$ in satisfactory conditions and there was no statistical significance when the values of the two groups were compared $(p>0.05)$

\begin{tabular}{|c|c|c|c|c|c|c|}
\hline $\begin{array}{c}\text { Period of ischemia / } \\
\text { mortality Number of animals } \\
\text { (groups of 5) }\end{array}$ & Death before 6 hours & $\begin{array}{c}\text { Survived } 6 \text { hours and } \\
\text { did not recover from } \\
\text { anesthesia }\end{array}$ & Survived 6 hours & Statistical significance \\
\hline $\begin{array}{c}30 \text { minutes continuous } \\
15 \text { minutes of ischemia }\end{array}$ & 2 & 2 & 1 & NS $(p>0,05)$ \\
\hline $\begin{array}{c}5 \text { minutes of reperfusion, plus } 15 \\
\text { minutes of ischemia }\end{array}$ & 4 & 0 & 1 & NS (p $>0,05)$ \\
\hline
\end{tabular}


reporting the darkening of the intestine of one of the four animals which held cuts in the parenchyma and resection of a hepatic lobe. The objective of the experiment was to evaluate the reduction in bleeding that occurs with compression of the portal triad and although the hepatic pedicle of the first rabbit operated was clamped for $1 \mathrm{~h}$, the animal survived, as well as three others. The eight patients died, and authors of the time are mentioned, Ponfick and Langenbuch, who reported the "dangerous congestion of the intestine" that accompanies the obstruction of the portal circulation and also the pulmonary thromboembolism originated in the hepatic vessels, defined as "common and fatal". Pringle also described quite current tactics, such as the section of the ligaments of the liver to improve the exposure of the organ during the operation, the section of the lower ribs and diaphragm when there was no tracheal intubation, as well as "packing" the wound and abbreviated laparotomy. Considering the time it was written, it is known that many concepts considered "current", have been used by the author and even with the resources now available, hardly any patient operated by him would be saved.

Tralhão et al. ${ }^{28}$, in Coimbra, used two tactical options to help assist the performance of elective liver resections in 61 patients. The intermittent Pringle maneuver was performed in 33 patients and selective clamping of the right or left branches of portal vein and the hepatic artery was used in 11 patients. The remaining 17 did not require specific maneuvers for the realization of hepatic resections. The authors have not found statistically significant differences with regard to morbidity, impact on clinical monitoring parameters and analysis of biochemical parameters, occurring changes only in the values of some liver enzymes.

Hirano et al. ${ }^{10}$, studying hypovolemic shock in rats, performed the Pringle maneuver for $15 \mathrm{~min}$. and found venous congestion with dilated veins and cyanosis of the small intestine and spleen in the first minutes after compression of the portal triad. In the study presented here congestion was found, but no cyanosis, and after the initial $15 \mathrm{~min}$., when hepatic reperfusion was performed in Group 3 for 5 min., it was noted that some mesenteric vessels remained turgid and bowel loops showed early signs of edema and circulatory changes, as it can be seen in Figure 3. The same authors studying only the acute period of the experiment, reported overall mortality of $9.3 \%$ (three animals out of 32 ), one $(12.5 \%)$ in the group that performed the Pringle maneuver and two (25\%) when the same maneuver was performed in animals in hypovolemic shock; the experiment showed, in addition to splanchnic venous congestion, petechiae in the intestinal loops and bloody exudate in the abdominal cavity. The study that took place here predicted the survival of rats for $6 \mathrm{~h}$, when biochemical and histological parameters would be evaluated, but the overall mortality of $40 \%$ (six out of 15 animals failed to survive the expected time), occurring death of two animals (13.3\%) before $6 \mathrm{~h}$ in the group where the continuous compression of the portal triad was performed for $30 \mathrm{~min}$. and the death of four animals (26.6\%) when hepatic reperfusion was performed for $5 \mathrm{~min}$. between two periods of $15 \mathrm{~min}$. of compression of the hepatic hilum resulted in the suspension of the experiment. Petechiae on the small intestine loops and bloody exudate in the cavity have been found (Figure 5). Reperfusion of the liver parenchyma after ischemic periods and the great splanchnic venous congestion during the clamping of the portal triad entail significant systemic consequences in our experiment that made the survival of animals unfeasible.

Although it is considered that the Pringle maneuver for more than $30 \mathrm{~min}$. in rats is accompanied by high mortality ${ }^{10}$, Unalp et al. ${ }^{29}$ have used it for 30 and $60 \mathrm{~min}$. in these animals, but the experiment ended after this period without any need for survival. Rocha et al. ${ }^{22}$, have occluded the abdominal aorta of rats to evaluate mesenteric ischemia for up to 90 min., but the experiment also included the removal of organs after short periods of reperfusion. In our study four animals of the group in which there was intermittent ischemia and two of the group in which ischemia was uninterrupted died before $6 \mathrm{~h}$. Although two animals survived until the end of the experiment, they did not recover the first anesthesia and possibly would not survive for a long time. It was expected a greater mortality of animals that remained for 30 min. with clamping portal triad, but four animals of the group in which intermittent ischemia was performed, died prematurely. Although no statistical significance between the mortality of Groups 2 and 3 has been evidenced, possibly the effects of the phenomena of ischemia and reperfusion contributed to these results.

In the late 1980s, with the development of the solution for hypothermic organ preservation at the University of Wisconsin, there was a great development of liver transplants. Hypothermic solution reduces the metabolism, the concentration of catabolic enzymes, cellular edema and acidosis, lessening the injury of the graft to be transplanted and its consequent dysfunction, accompanied by high morbidity and mortality 8,18 . Decreased oxygenation of hepatocytes during ischemia results in ATP depletion, accumulation of hydrogen ions, electrolyte abnormalities of sodium and calcium, with activation of enzymes and hepatic cell edema, microcirculatory dysfunction, accumulation and activation of neutrophils, release of free radicals, inflammatory cytokines, including tumor necrosis factor alpha (TNF- $\alpha$ ), interleukin-1 (IL-1) and proteases. T lymphocytes activated in this situation potentiate the cellular response ${ }^{3}$. The restoration of blood flow results in poorly understood phenomena involving complex mechanisms and cellular metabolic pathways that aggravate ischemic injury. Endothelial dysfunction occurs, activation of Kupffer cells, sequestration of leukocytes, platelet aggregation, microcirculation disorders, releasing free radicals, nitric oxide and other proinflammatory mediators, aggravating the injury ${ }^{18}$. Free radicals are important to the development of inflammatory phenomena, mainly because they react with the phospholipids of the cell membrane, triggering the disintegration of this membrane with irreversible cell damage, generating chemotactic factors and polymorphonuclear leukocyte accumulation in injured tissues $^{12,23}$. The phenomena described in this situation are complex, involve mechanisms still poorly understood and represent broad research field with a lot of data to be studied.

The presentation of adverse outcomes in clinical practice and the difficulties related to the theme approach have always led to discussions; many important articles discuss the ethical aspects of research and failures, including willful, in the conduct of studies in various countries $2,6,7,20,25$. In 1994, Altman ${ }^{1}$ published an editorial in the prestigious British Medical Journal, with approximately one page, stating that one needs less medical research, but studies with higher quality; he reported the frequent occurrence of methodology failures (intentional or through ignorance), the use of incorrect methods of analysis, particularly the choice of statistical method, when appropriate, would be a way to minimize the flaws in the interpretation of results. The repercussion of the text named "the scandal of poor medical research" was swift, as ten Letters to the Editor, published in the same volume of the journal, occupied at least the triple of space of the first editorial|4,7,11,13,16,17,19,26,27,30. One of the letters published in the same volume quoted an English study on breast cancer, published in 1990 in The Lancet, which was widely reported even by the lay press, but later it became evident that the collection of monitoring data of the study was flawed and the statistical analysis incorrect, being defined as "not only is bad research 'unethical in itself', but in this case further ethical problems arise because of the damage done to women who took part in the survey". After the negative repercussions, one 
of the authors of the study committed suicide ${ }^{6}$, but the editor of The Lancet at the time did not accept to publish a formal apology, stating that this attitude should be reserved for cases of fraud and not when an error occurs, being criticized for his attitude, once the article, with inappropriate conclusions, had wider repercussions and continued to be quoted worldwide ${ }^{7}$.

In many situations, the use of experimental animals is essential, but there should be a critical review of experimental models periodically, preventing unnecessary deaths $3^{3,20}$ and respecting the humanitarian principle of animal experimentation known as the three R's: Reduction, Refinement and Replacement.

\section{CONCLUSIONS}

The initial purpose of this study, the analysis of biochemical and histological parameters of liver, could not be achieved due to the mortality of animals, showing that the effects of the Pringle maneuver are also significant on the splanchnic territory, even with intermittent ischemia of the portal triad. Respect for ethical principles of animal experimentation has made the study to be interrupted due to the adverse outcomes presented in order to avoid that this method, which implies the survival of animals for a longer period after complete reperfusion, to be repeated in other studies.

\section{REFERENCES}

1. Altman DG. The scandal of poor medical research. BM. 1994;308:283-4

2. Ankier SI. Dishonesty, misconduct and fraud in clinical research: an international problem. J Intern Med Res 2002;30:357-65.

3. Braz MM, Mir ME, Castro MBJ, Ramírez AC, Ramalho FS, Peralta C The current state of knowledge of hepatic ischemia-reperfusion injury based on its study in experimental models. J Biomed Biotech 2012;2012:1-20.

4. Dudley $\mathrm{H}$. The scandal of poor medical research. Statisticians can be inconsistent and uncommunicative. BMJ1994;308:592.

5. Evora PRB, Castro e Silva O. Choque circulatório, SIRS e disfunção endotelial. In: Petroianu A, editor. Clínica Cirúrgica do Colégio Brasileiro de Cirurgiões. São Paulo: Atheneu; p. 109-19.

6. Fallowfield L. Cancer study controversy. BMJ1994;308:593.

7. Goodare $\mathrm{H}$. The scandal of poor medical research. Wrong results should be withdrawn. BMJ 1994:308:593.

8. 't Hart NA, van der Plaatsb A, Leuveninka HGD, Wiersema-Buista $J$, Olingac $\mathrm{P}$, van Luynd MJA, et al. Initial blood washout during organ procurement determines liver injury and function after preservation and reperfusion. Am J Transplant 2004;4:1836-44.

9. Hirano ES, Mantovani M, Morandin RC, Fontelles MJP. Modelo experimental de choque hemorrágico. Acta Cir Bras 2003;18(5):465-70

10. Hirano ES, Mantovani M, Morandin RC. Isquemia e reperfusão hepática total em condições de normalidade e sob estado de choque hemorrágico controlado: efeitos no seqüestro de neutrófilos no rim do rato. Acta Cir Bras 2005;20(4):292-9.
11. Ind TEJ. The scandal of poor medical research. Doctors lose their battle with statistics. BMJ 1994;308:592.

12. Jaeschke $\mathrm{H}$, Smith CV, Mitchell JR. Reactive oxygen species during ischemia-reflow injury in isolated perfused rat liver. J Clin Invest 1988;81:1240-6.

13. Jones R, Scouller J, Grainger F, Lachian M, Evans S, Torrance N.The scandal of poor medical research. Sloppy use of literature often to blame. BMJ 1994;308:591.

14. Kim SK, Lim HK, Ryu J, Choi D, Lee WJ, Lee JY, et al. Radiofrequency ablation of rabbit liver in vivo: effect of the Pringle maneuver on pathologic changes in liver surrounding the ablation zone. Korean J Radiol 2004;5:240-9.

15. Kinshoku MR, Rodriguez CAL, Fidalgo RS, Duran CCG, Leme PLS, Duarte IS. Uso racional de modelos animais para pesquisa e ensino de microcirurgia. Rev Col Bras Cir 2012;39(5):414-417.

16. Masterson GR, Ashcroft GS. The scandal of poor medical research. Better libraries and more journal clubs would help. BMJ 1994;308:592-3.

17. Matheson NA. The scandal of poor medical research ... while poor leadership fuels mediocrity. BMJ 1994;308:591.

18. Miranda LEC, Viaro F, Ceneviva R, Evora PRB. As bases experimentais da lesão por isquemia e reperfusão do fígado: revisão. Acta Cir Bras 2004;19(1):3-12.

19. Morris JA. The scandal of poor medical research. Theory must drive experiment. BMJ 1994;308:592.

20. Petroianu A. Clínica Cirúrgica do Colégio Brasileiro de Cirurgiões. São Paulo: Atheneu; 2010. Capítulo 56, Pesquisa em cirurgia; $p$. 847-59.

21. Pringle $\mathrm{JH}$. Notes on the arrest of hepatic hemorrhage due to trauma. Ann Surg 1908;48:541-9.

22. Rocha BC, Mendes RRS, Lima GV, Albuquerque GS, Araújo LL, Jesus MNS et al. Experimental model of mesenteric ischemia/ reperfusion by abdominal aorta clamping in Wistar rats. Rev Col Bras Cir 2012;39(3):207-10.

23. Schoenberg $M H$, Buchler $M$, Gaspar $M$, Stinner A, Younes $M$ Melzner I, et al. Oxygen free radicals in acute pancreatitis of the rat. Gut 1990;31:1138-43.

24. Silva AR, Kriguer-Júnior RJ, Serigiolle LC, Gomes HMP, Rodrigues $\mathrm{DAB}$, Leme PLS. Aumento do volume do baço em modelo experimental de hipertensão portal pré-hepática em ratos. Arq Bras Cir Dig 2013;26(3):206-212.

25. Sutcliffe KM, Lewton E, Rosenthal MM. Communication failures: an insidious contributor to medical mishaps. Acad Med 2004;79:186-94.

26. Sykes A. The scandal of poor medical research. Undergraduates learn the wrong lessons. BMJ 1994;308:592.

27. Tallis RC. The scandal of poor medical research. Researchers forced to do boring research... BMJ 1994;308:591.

28. Tralhão JG, Hoti E, Oliveiros B, Abrantes AM, Botelho MF, CastroSousa F. Intermittent Pringle maneuver and hepatic function: perioperative monitoring by noninvasive ICG-clearance. World J Surg 2009;33(12):267-34.

29. Unalp OV, Aydin U, Yazici P, Nart D, Yenisey C, Kavak T et al. The effects of the Pringle maneuver on the pancreas: can octreotide be protective? J Pancreas 2008;10(3):284-91.

30. Walsworth-Bell JP. The scandal of poor medical research. Be positive about research. BMJ 1994;308:593. 